\title{
Distribution of Radioactive Elements and Their Relation to the Radiogenic Heat Production at Jabal Kharazah Area, North Eastern Desert, Egypt
}

\author{
Mohamed A. Shaheen \\ Exploration Sector, Nuclear Materials Authority, Maadi, Cairo, Egypt \\ Email: mamshaheen2002@yahoo.vom
}

How to cite this paper: Shaheen, M. A. (2020). Distribution of Radioactive Elements and Their Relation to the Radiogenic Heat Production at Jabal Kharazah Area, North Eastern Desert, Egypt. Journal of Geoscience and Environment Protection, 8, 155-168. https://doi.org/10.4236/gep.2020.84011

Received: March 29, 2020

Accepted: April 26, 2020

Published: April 29, 2020

Copyright $\odot 2020$ by author(s) and Scientific Research Publishing Inc. This work is licensed under the Creative Commons Attribution International License (CC BY 4.0).

http://creativecommons.org/licenses/by/4.0/

\begin{abstract}
A map of radiogenic heat production RHP was constructed from airborne spectral gamma-ray data of Jabal Kharazah area, North Eastern Desert, Egypt. The study area possesses a range of RHP varying from 0.2 to $5.7 \mu \mathrm{W} / \mathrm{m}^{-3}$ with an average value $1.38 \mu \mathrm{W} / \mathrm{m}^{-3}$, while the standard deviation value is $0.7 \mu \mathrm{W} / \mathrm{m}^{-3}$. The maximum values are associated with the acidic rocks in the northeast, southeast and a small portion in the northwest zones. About $68 \%$ of the readings are higher than the average RHP value in the area, thus Jabal Kharazah area can be considered as heat production area due to the relatively high radioactive mineral concentrations. There are excellent relationships between the derived RHP and the three radioactive elements, Uranium (eU), Thorium (eTh) and Potassium (K).
\end{abstract}

\section{Keywords}

Radiogenic Heat Production RHP, Jabal Kharazah Area, Airborne Spectral Gamma-Ray

\section{Introduction}

Jabal Kharazah area is located in the North Eastern Desert of Egypt. The study area is mainly covered by the Precambrian basement rocks as well as Cretaceous and Quaternary sediments as shown in Figure 1. This area enclosed Wadi Dara area which was characterized earlier as radiogenic heat producing area (Aziz, 2014). Radiogenic heat production RHP rate is a physical property defining the amount of heat liberated in a unit time per unit volume of rock by the decay of unstable radioactive isotopes; in unit of $\mu \mathrm{W} / \mathrm{m}^{-3}$ (Clauser, 2011). During radioactive decay, 

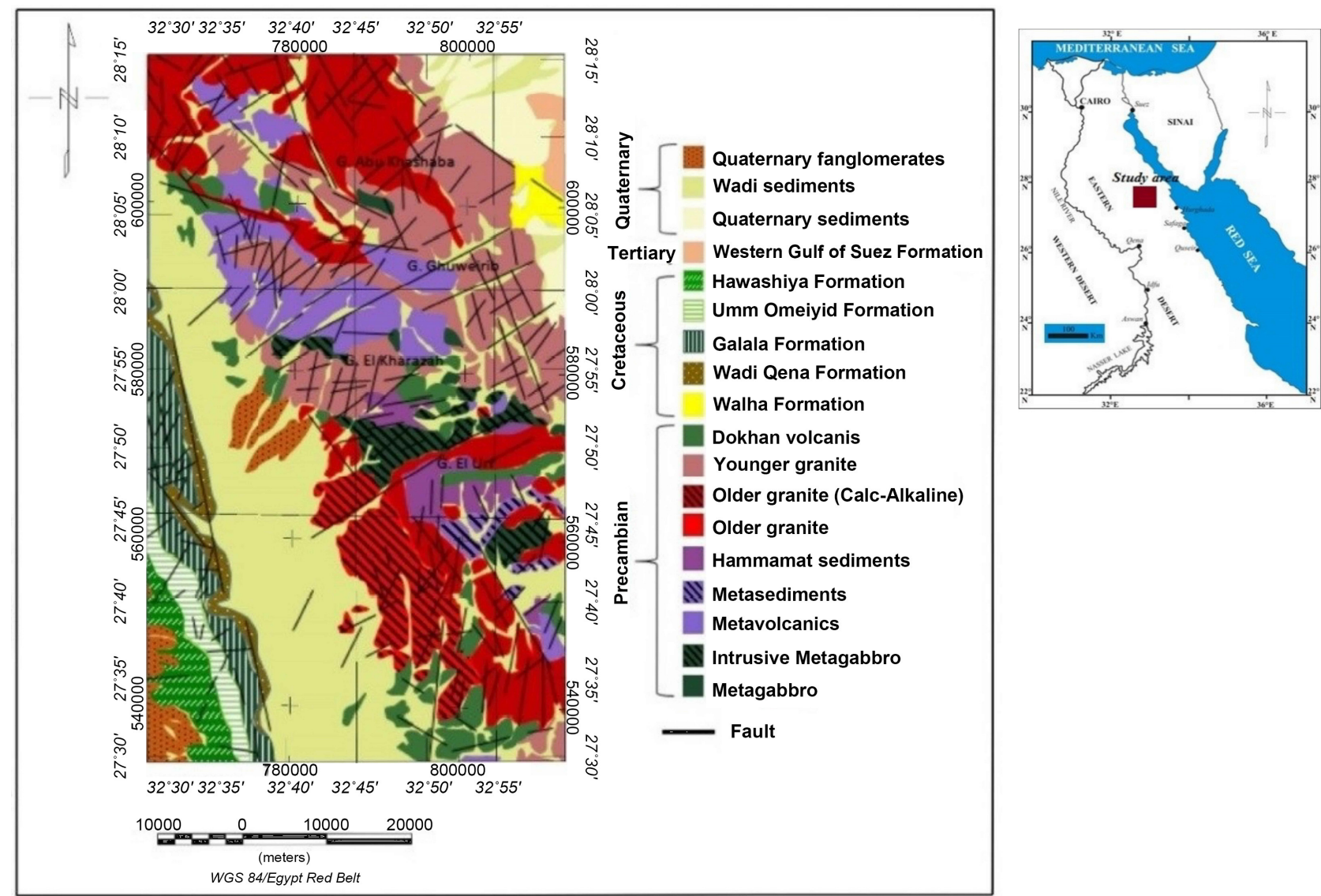

Figure 1. Location and geologic map of Jabal Kharazah area, North Eastern Desert, Egypt after (Conoco, 1987, 1988).

mass is converted into energy, except for the tiny amount associated with the antineutrinos and neutrinos generated in $\beta--\beta+-$ decay or electron capture. Respectively, all of this energy is converted into heat (Clauser, 2011).

RHP in crustal rocks is dominated by contributions from three radioactive elements, namely uranium, thorium, and potassium. These have long half-life times, comparable to the age of Earth, sufficient abundances in rocks and significant proportions of their emission are fully converted to heat within the rocks. (Pollack \& Chapman, 1977) showed that RHP contributes about $45 \%$ of the surface heat flow observed over the continents, while (Lachenbruch, 1970), (Swanberg, 1972) and (Lowrie, 1997) showed that its magnitude exponentially decreases with depth. RHP is high in the upper crust and can be estimated as a function of crustal age at any depth within the crust. In contrast, RHP is always low at the mantle reaching $1-2 \mu \mathrm{W} / \mathrm{m}^{-3}$ mostly due to the total heat flow. The main purpose of this paper is to provide new insights on the geothermal setting of the Jabal Kharazah area based on the existing airborne gamma-ray data. We attempt to map surface RHP from the airborne gamma-ray data. RHP can be used for several purposes (Bücker \& Rybach, 1996). It can be used for explanation of temperature variations with depth and interpretation of existing heat flow variations. Also it can be used in selecting suitable new sits for making heat flow and/or heat production measurements. 


\section{Geologic Setting}

The study area is composed of different exposures rock units which extend from Precambrian to Quaternary sediments. The exposed Precambrian rocks of the study area are sorted from old to recent as follow: metagabbro, intrusive metagabbro, metavolcanics, metasediments, Hammamat sediments, older granite, older granite (calc-alkaline), younger granite and Dokhan volcanics, while the Cretaceous rocks are sorted in the same manner as Malha Formation, Wadi Qena Formation, Galala Formation, Umm Omeiyid Formation and Hawashiya Formation, also the western Gulf of Suez Formation is exposed and represents the Tertiary exposed rocks. Finally, the Quaternary sediments are composed of wadi sediments and Quaternary conglomerates. Complexity of the structure of the study area is tightly related to the regional structures in the North Eastern Desert affecting faults and fractures trending NNW-SSE, NNE and ENE-WSW according to (Conoco, 1987, 1988).

\section{Geophysical Data}

The study area was surveyed by measuring the spectrometric data using $\mathrm{NaI}$ crystals, producing maps of TC in (Ur), eU in (ppm), eTh in (ppm) and $\mathrm{K}$ in (\%) as shown respectively in Figures 2-5. The survey parameters were $1 \mathrm{~km}$ in flight line spacing while the station separation was about 92.65 meters.

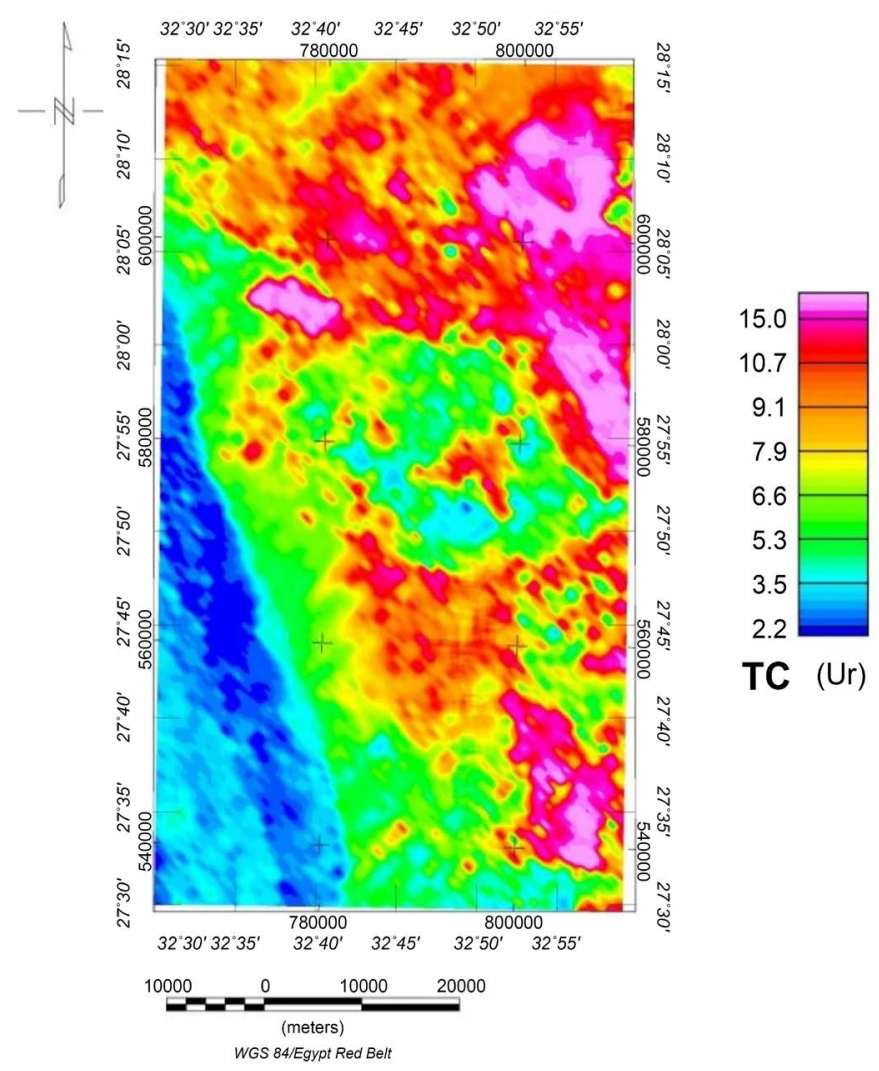

Figure 2. The total counts in (Ur) for Jabal Kharazah area, Northern Eastern Desert, Egypt. 


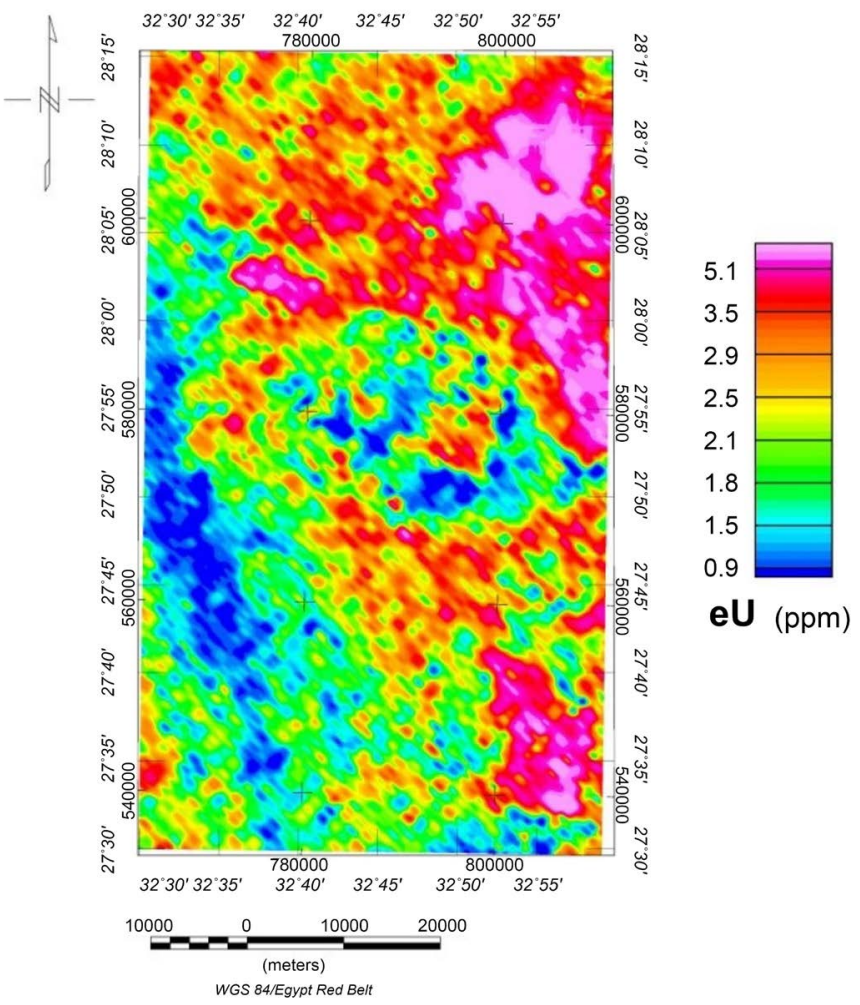

Figure 3. The equivalent uranium in ( $\mathrm{ppm})$ for Jab Kharazah area, Northern Eastern Desert, Egypt.

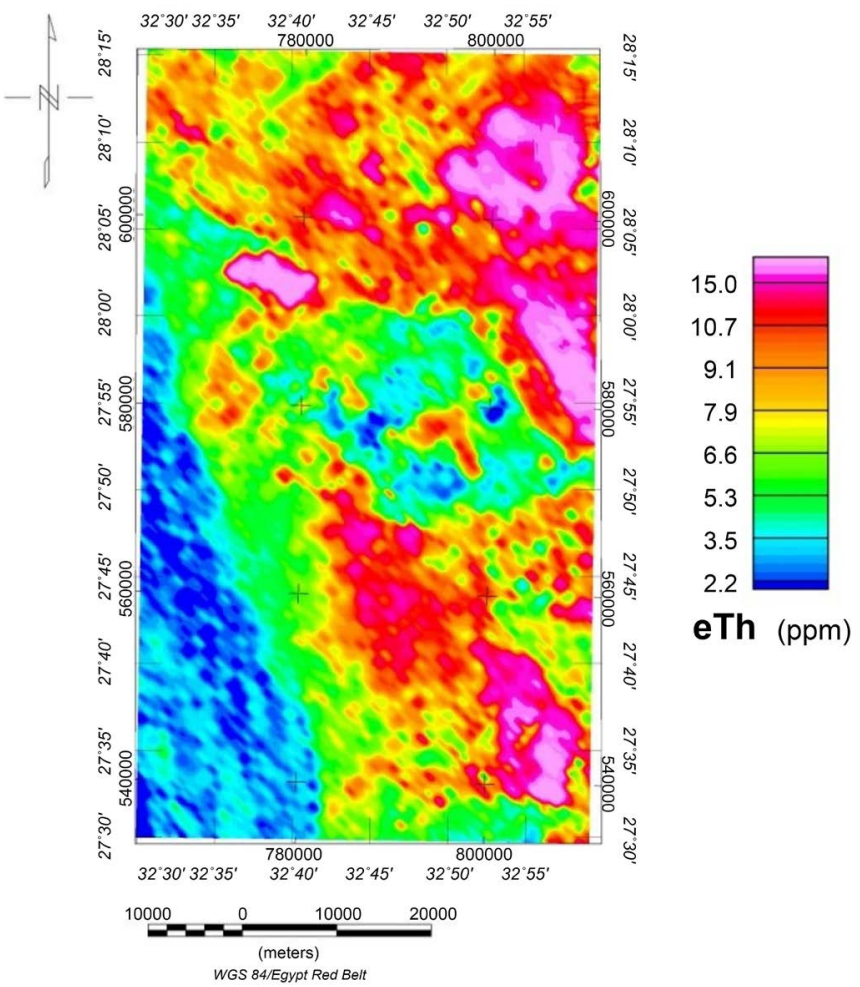

Figure 4. The equivalent thorium in (ppm) for Jabal Kharazah area, Northern Eastern Desert, Egypt. 


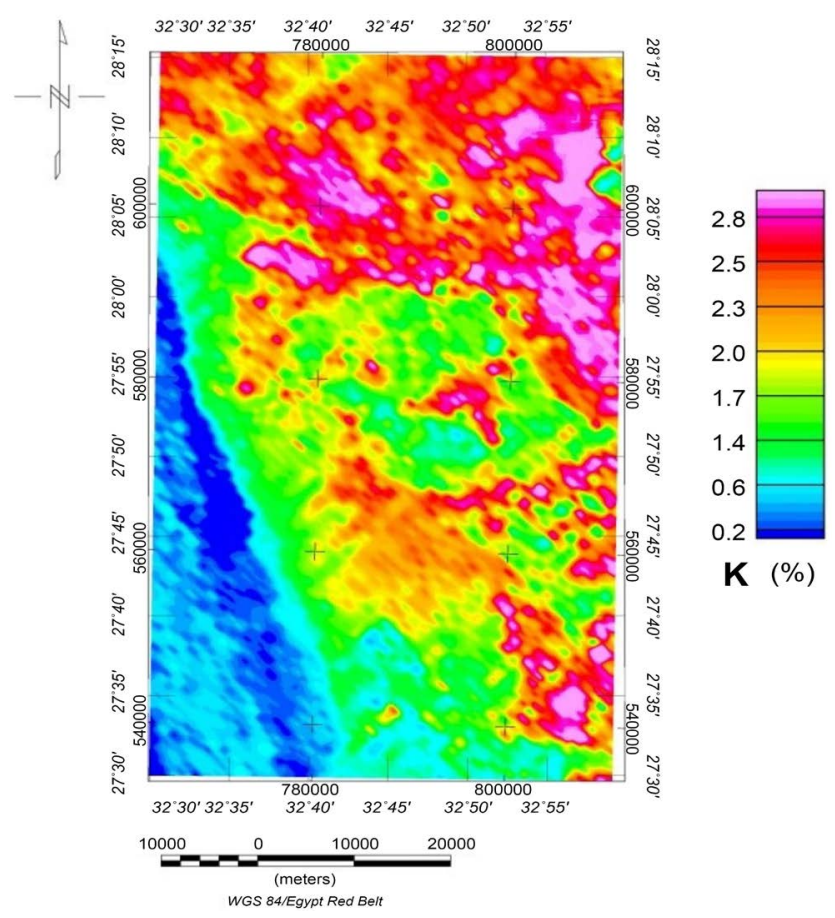

Figure 5. The potassium concentration in (wt\%) for Jabal Kharazah area, Northern Eastern Desert, Egypt.

\section{Radiogenic Heat Production}

The main interior sources of heat in Earth are the heat content of the primitive Earth directly after formation due to gravitational shrinkage and the decay of unstable radioactive isotopes. The radiogenic decay of the unstable isotopes of uranium $(238 \mathrm{U}, 235 \mathrm{U})$, thorium $(232 \mathrm{Th})$ and potassium $(40 \mathrm{~K})$ delivers the largest internal source of heat; these radionuclides are enriched in the Earth's crust and mantle (McDonough \& Sun, 1995; Jaupart et al., 2007; Stacey \& Davis, 2008). In this study, an attempt is presented to produce surface radioactive heat production map using the airborne spectral gamma-ray data.

\section{Calculating RHP Rate}

RHP has been calculated from concentrations of radio-elements measured in the laboratory (Fernàndez et al., 1998) and directly from gamma-ray logs (Bücker \& Rybach, 1996). Also, radioactive heat production has been estimated from airborne gamma-ray data (Thompson et al., 1996; Salem et al., 2005). Heat production of a rock is the total heat produced by the radioactive isotopes of $U$, Th, and $\mathrm{K}$. It is defined as the quantity of heat produced by radioactivity in unit volume of the rock per unit time, and is expressed in $\mu \mathrm{W} / \mathrm{m}^{-3}$. It can be estimated using the following relation after (Rybach, 1986):

$$
\mathrm{RHP}\left(\mu \mathrm{W} / \mathrm{m}^{-3}\right)=\rho(0.0952 \mathrm{CU}+0.0256 \mathrm{CTh}+0.0348 \mathrm{CK})
$$

where $\rho$ is the dry density of rock $\left(\mathrm{g} / \mathrm{cm}^{3}\right)$ and CU, CTh and CK are the concentrations of $\mathrm{U}$ and $\mathrm{Th}$ in ppm and $\mathrm{K}$ in \% respectively. Average density for each rock unit is presented in (Table 1) after (Shaaban, 1973). Besides, the measurements of radioelements with each rock unit $\mathrm{eU}$, eTh and $\mathrm{K}$ which are used to cal- 
culate the radioactive heat production. The resulted data then interpolated using Kriging method and contoured producing a map which represents the spatial distribution of RHP within the studied area and facilitates its comparison with other maps. In order to get the best results for delineating the surface radioactive heat production in the study area, the geologic map is prepared and re-projected by outlining different rock units and subsequently estimating the radioactive heat production of each rock unit. The surface radioactive heat production (Figure 6) represents the final product, which displays the anomalous radioactive heat production zones in the study area. (Hasterok et al., 2018) studied the plutonic-metaplutonic rocks, volcanic-metavolcanic rocks and sedimentary rocks using the same equation to calculate RHP. They found that the lowest calculated RHP value of the plutonic and metaplutonic rocks is $\left(0.095 \mu \mathrm{W} / \mathrm{m}^{-3}\right)$ related to the predotgabbro while the highest RHP value is $\left(3.4 \mu \mathrm{W} / \mathrm{m}^{-3}\right)$ related to the foid syenite. The lowest RHP value of volcanic and metavolcanic rocks is $\left(0.54 \mu \mathrm{W} / \mathrm{m}^{-3}\right)$ related to the komatiiet while the highest RHP value is $\left(3.4 \mu \mathrm{W} / \mathrm{m}^{-3}\right)$ related to the phonolite. The lowest RHP value of the sedimentary rocks is $\left(0.31 \mu \mathrm{W} / \mathrm{m}^{-3}\right)$ related to the quartz arenite while the highest RHP value is $\left(11 \mu \mathrm{W} / \mathrm{m}^{-3}\right)$ related to the oxide rock unit.

Figure 6 illustrates the distribution of RHP values in the study area, where more

Table 1. Average denisty for each rock unit.

\begin{tabular}{cc}
\hline Rock units & Density $\left(\mathrm{gm} / \mathrm{cm}^{3}\right)$ \\
\hline Sedimentary & 2.41 \\
Metavolcanics & 2.64 \\
Hammamat sediments & 2.61 \\
Dokhan volcanics & 2.60 \\
Granite & 2.59 \\
\hline
\end{tabular}

a. After Shaaban, 1973.

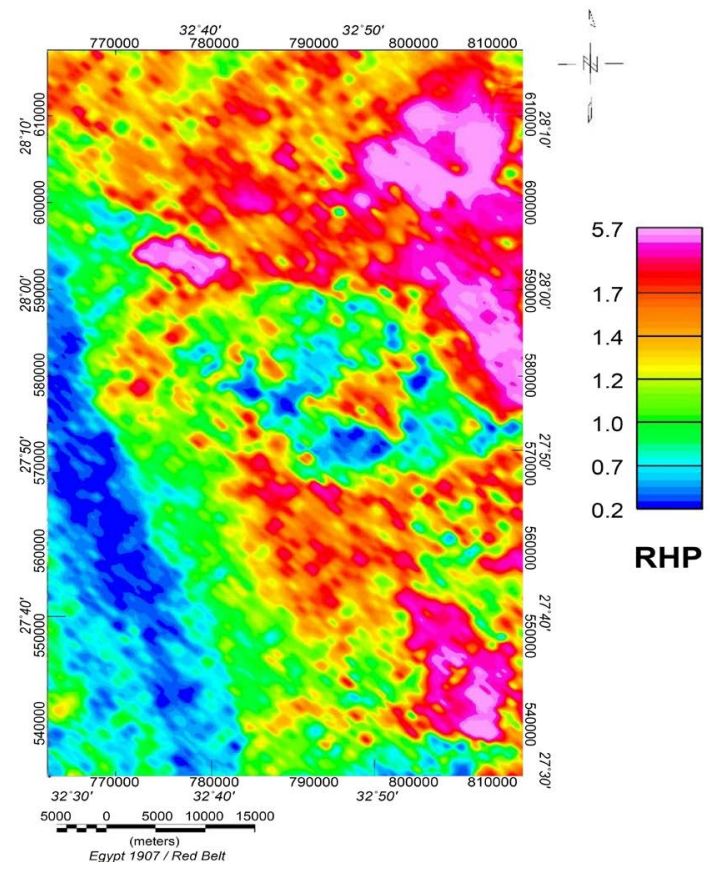

Figure 6. The RHP rate of Jabal Kharazah, Northern Eastern Desert, Egypt. 
than 95\% from the RHP values are more than the average of RHP in the crust (1 $\mu \mathrm{W} / \mathrm{m}^{-3}$ ), while about $68 \%$ from data values are more than the average RHP value in the study area $\left(1.38 \mu \mathrm{W} / \mathrm{m}^{-3}\right)$, thus the study area can be considered as heat producing area due to the relatively high radioactive minerals concentrations.

\section{Data Interpretation}

The RHP values distributed in the study area were calculated and shown in Figure 6. It was found that, the RHP values range from 0.2 to $5.7 \mu \mathrm{W} / \mathrm{m}^{-3}$ with an average value of $1.38 \mu \mathrm{W} / \mathrm{m}^{-3}$. On the other hand, the standard deviation value is $0.71 \mu \mathrm{W} / \mathrm{m}^{-3}$. From the average and standard deviation values the distribution of the RHP property can be delineated. The maximum values are present in the northern, northeastern and northwestern zones of the central part of the study area, which contain high values of the radioactive elements associated with the younger granite $\left(5.69 \mu \mathrm{W} / \mathrm{m}^{-3}\right)$ and older granite $\left(4.54 \mu \mathrm{W} / \mathrm{m}^{-3}\right)$, as well as traces in wadi sediments $\left(4.06 \mu \mathrm{W} / \mathrm{m}^{-3}\right)$ due to uranium migration. Meanwhile the minimum values are present associated with Cretaceous, Tertiary and Quaternary sediments as well as different Precambrian rocks as intrusive gabbros $\left(3.29 \mu \mathrm{W} / \mathrm{m}^{-3}\right)$, metagabbro $\left(2.6 \mu \mathrm{W} / \mathrm{m}^{-3}\right)$, metasediments $\left(2.44 \mu \mathrm{W} / \mathrm{m}^{-3}\right)$, Dokhan volcanics $(2.34$ $\left.\mu \mathrm{W} / \mathrm{m}^{-3}\right)$ and Hammamat sediments $\left(2.3 \mu \mathrm{W} / \mathrm{m}^{-3}\right)$.

The threshold value of RHP was calculated from the following equation:

Threshold value $=$ Mean $+2 \times($ Standard Deviation $)$

By superimposing the heat production map (Figure 6) over the geologic map (Figure 1) it was possible to allocate and define characteristic RHP values pertaining each geologic rock unit. The data from $\mathrm{TC}, \mathrm{eU}$, eTh and $\mathrm{K}$ maps were taken into account. In this way the geologic boundaries between rock units were redefined.

\section{Binary Relationships}

Regression analysis or binary relation diagram is a form of predictive modelling technique which investigates the relationship between a dependent (target) and independent variable (s) (predictor). This technique is used for forecasting, time series modelling and finding the causal effect relationship between the variables. It might also considered as a set of statistical processes for estimating the relationships between a dependent variable (often called the "outcome variable") and one or more independent variables (often called "predictors", "covariates", or "features"). The most common form of regression analysis is linear regression, in which a researcher finds the line (or a more complex linear combination) that most closely fits the data according to a specific mathematical criterion. It can define the relation as strong from the correlation coefficient value $(r)$ and the resulted equation can be used to derive a property from other. All RHP values were treated statistically to define the RHP values of different rock units to describe the different relationships. Simple straight line relationships were supposed, supported by the elongated relationships. Consequently straight line relations were calculated as shown in Figure 7. The straight line relationships represent a guide to the expected RHP values in other similar rock types in the surrounding areas. 


\section{Dokhan volenics}

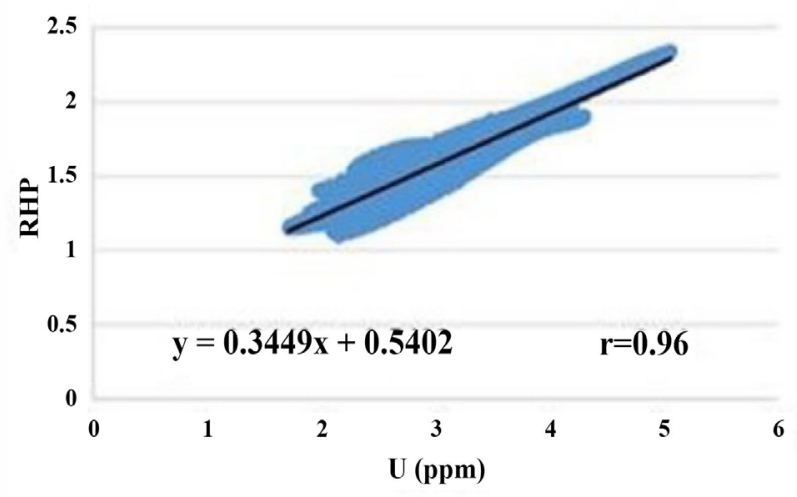

\section{Dokhan volcnics}
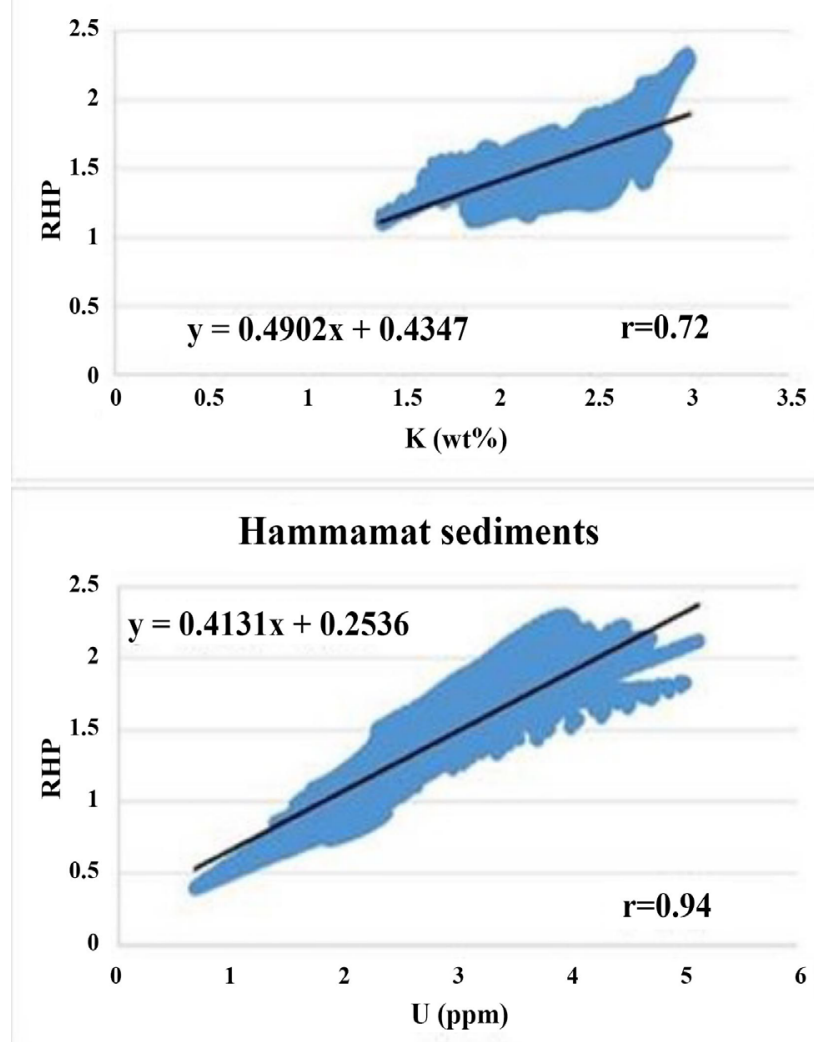

Hammamat sediments

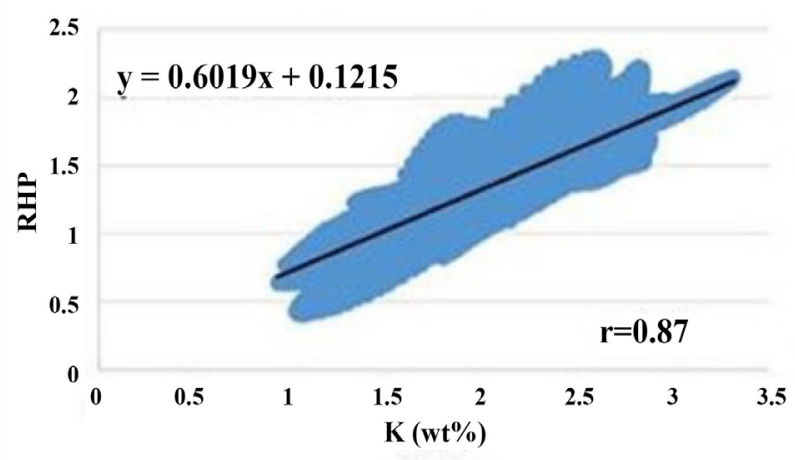

Dokhan volcnics

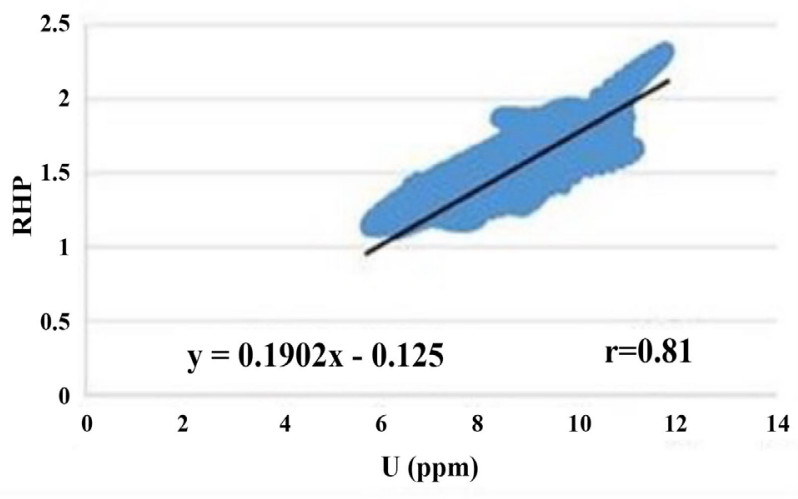

Dokhan volcnics

\begin{tabular}{|c|c|c|c|c|c|c|}
\hline & Mean & G. mean & Min. & Max. & Variance & Std. Dev. \\
\hline Rhp & 1.59 & 1.57 & 1.10 & 2.34 & 0.06 & 0.24 \\
\hline U & 3.03 & 2.96 & 1.71 & 5.07 & 0.43 & 0.66 \\
\hline Th & 9.00 & 8.94 & 5.69 & 11.80 & 1.01 & 1.00 \\
\hline K & 2.35 & 2.32 & 1.38 & 2.98 & 0.12 & 0.35 \\
\hline
\end{tabular}

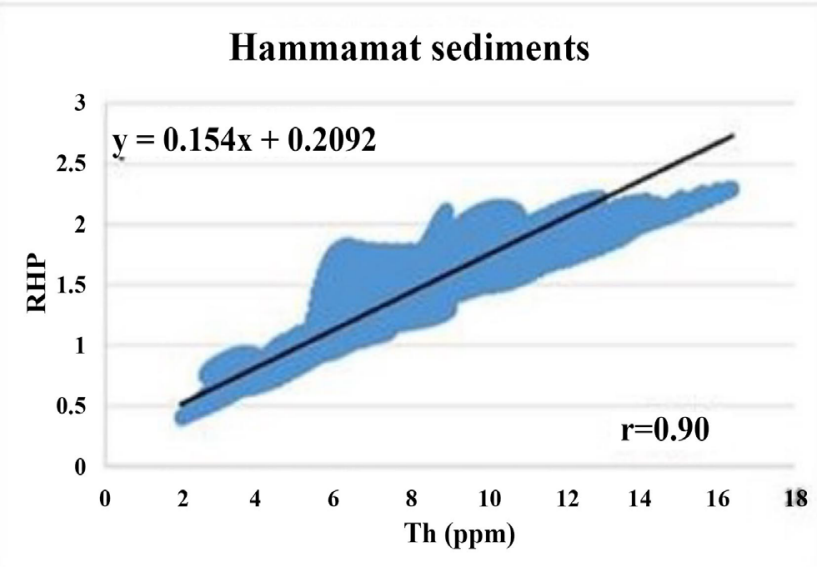

Hammamat sediments

\begin{tabular}{|c|c|c|c|c|c|c|}
\hline & Mean & G. mean & Min. & Max. & Variance & Std. Dev. \\
\hline Rhp & 1.41 & 1.37 & 0.40 & 2.30 & 0.10 & 0.32 \\
\hline $\mathrm{U}$ & 2.79 & 2.69 & 0.67 & 5.13 & 0.52 & 0.72 \\
\hline Th & 7.77 & 7.52 & 1.97 & 16.40 & 3.43 & 1.85 \\
\hline K & 2.13 & 2.08 & 0.93 & 3.32 & 0.21 & 0.45 \\
\hline
\end{tabular}


Intrusive metagabbros

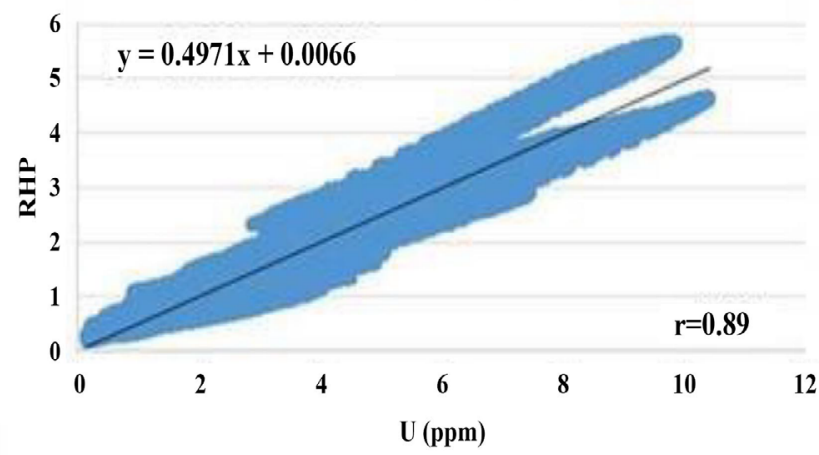

Intrusive metagabbros
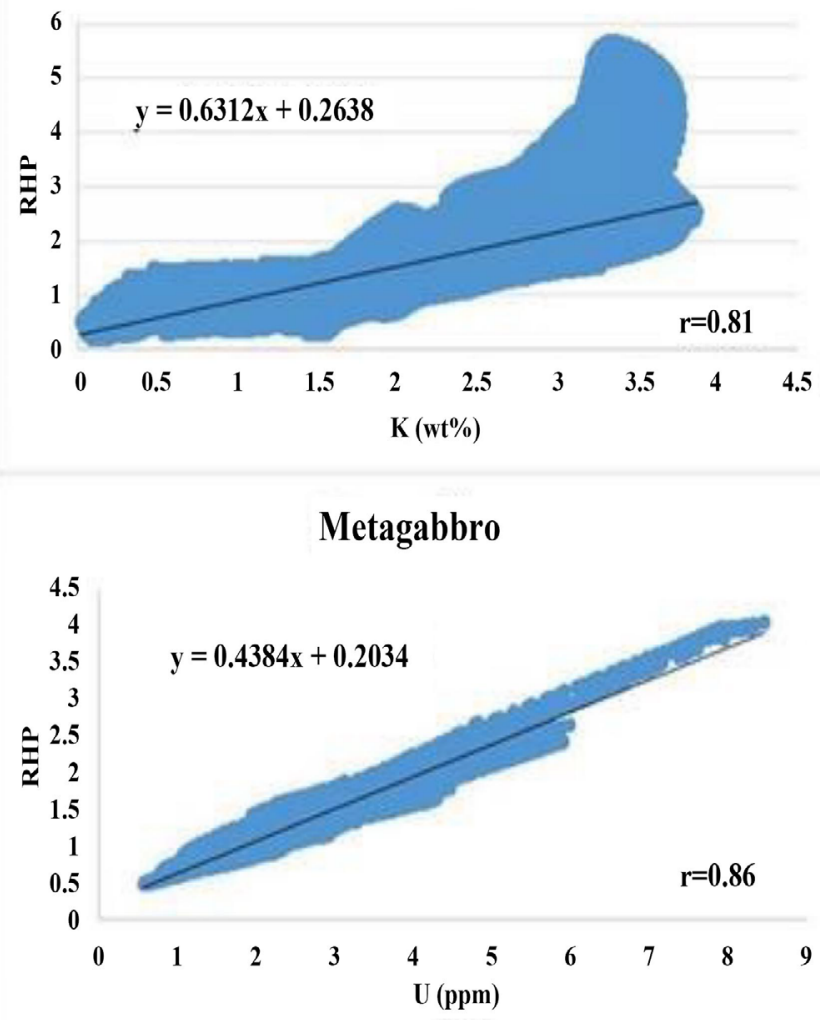

Metagabbro

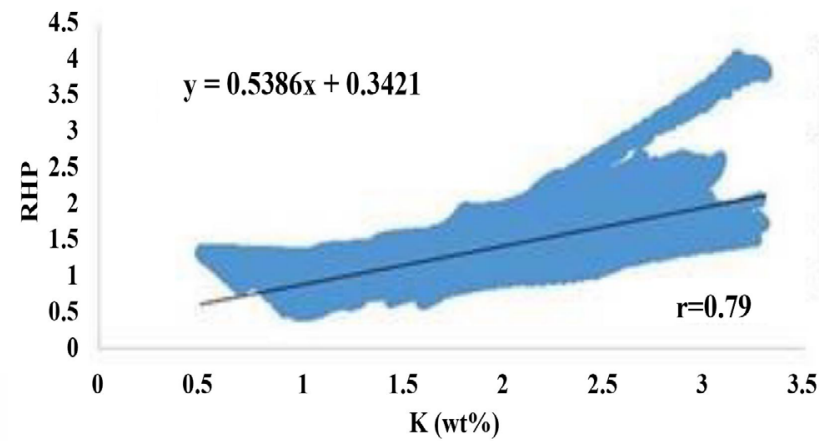

Intrusive metagabbros

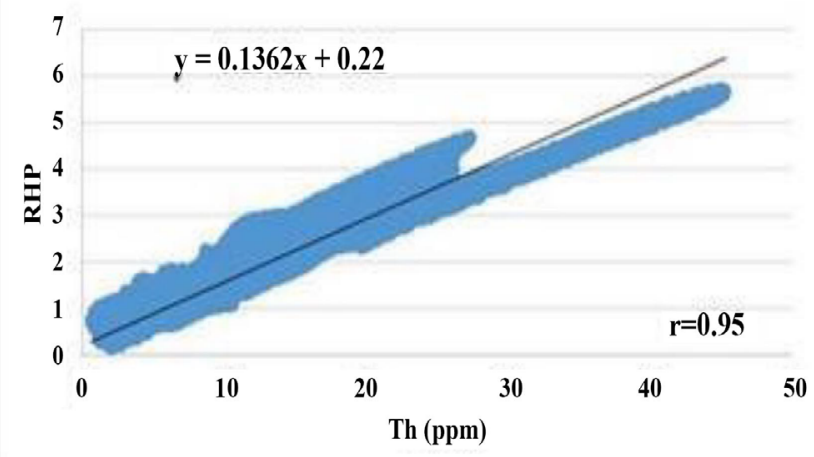

Intrusive metagabbros

\begin{tabular}{|c|c|c|c|c|c|c|}
\hline & Mean & G. mean & Min. & Max. & Variance & Std.Dev. \\
\hline Rhp & 1.29 & 1.22 & 0.47 & 3.29 & 0.22 & 0.47 \\
\hline U & 2.47 & 2.29 & 0.56 & 8.48 & 1.07 & 1.03 \\
\hline Th & 7.99 & 7.58 & 3.67 & 26.15 & 7.83 & 2.80 \\
\hline K & 1.68 & 1.56 & 0.50 & 3.32 & 0.43 & 0.66 \\
\hline
\end{tabular}

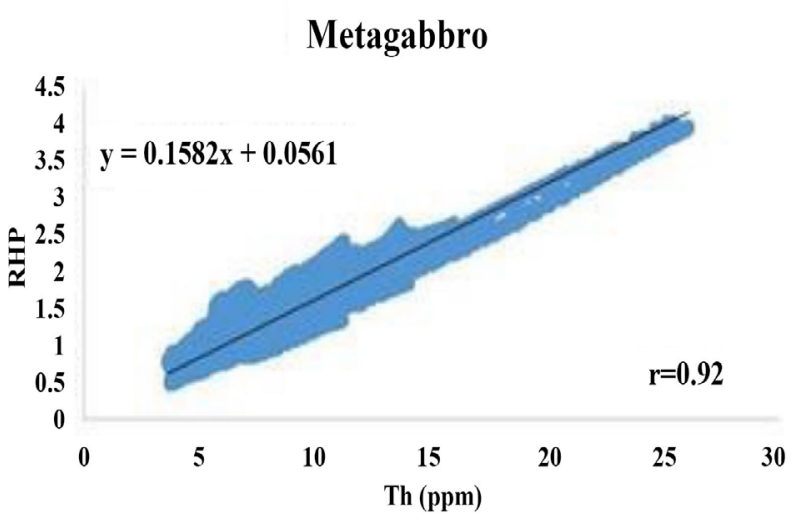

Metagabbro

\begin{tabular}{|c|c|c|c|c|c|c|}
\hline & Mean & G. mean & Min. & Max. & Variance & Std.Dev. \\
\hline Rhp & 1.18 & 3.73 & 0.4 & 2.6 & 3.01 & 0.45 \\
\hline U & 2.36 & 1.90 & 0.56 & 8.77 & 0.51 & 0.71 \\
\hline Th & 7.3 & 4.57 & 0.78 & 26.15 & 7.56 & 2.75 \\
\hline K & 1.45 & 0.75 & 0.07 & 3.32 & 0.31 & 0.56 \\
\hline
\end{tabular}



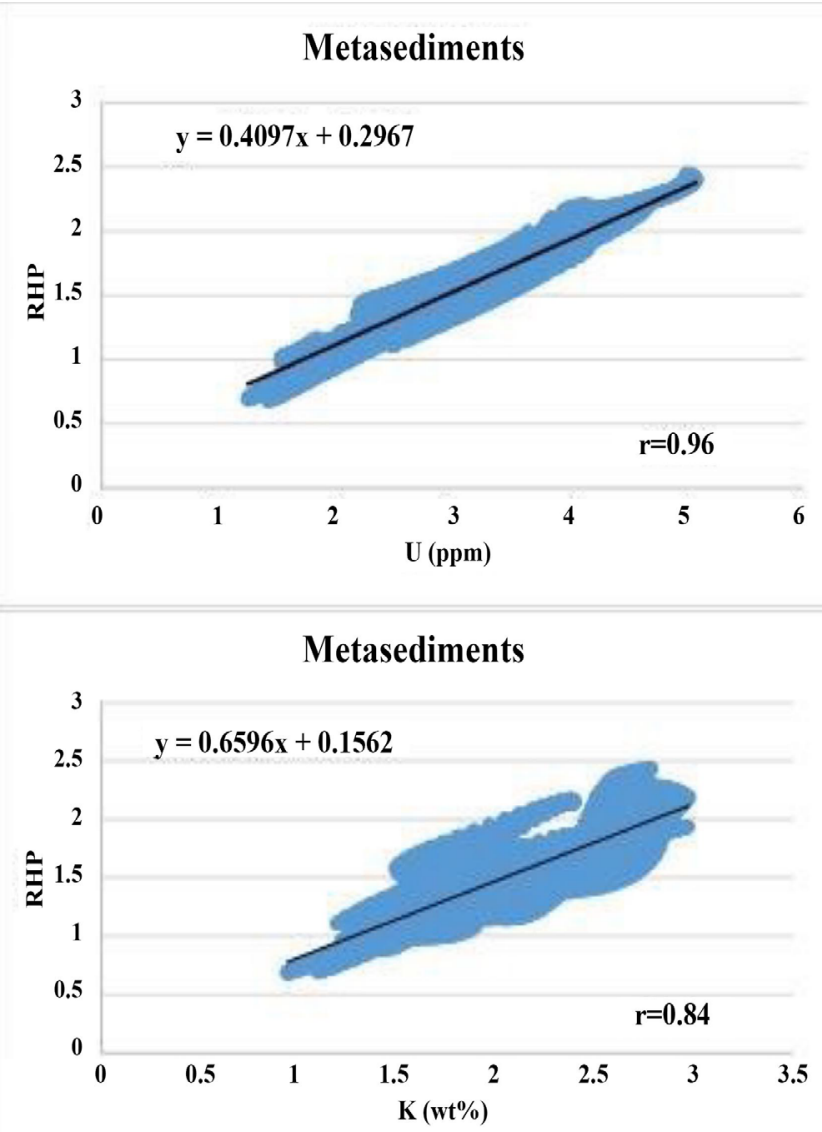

Metavolcanics

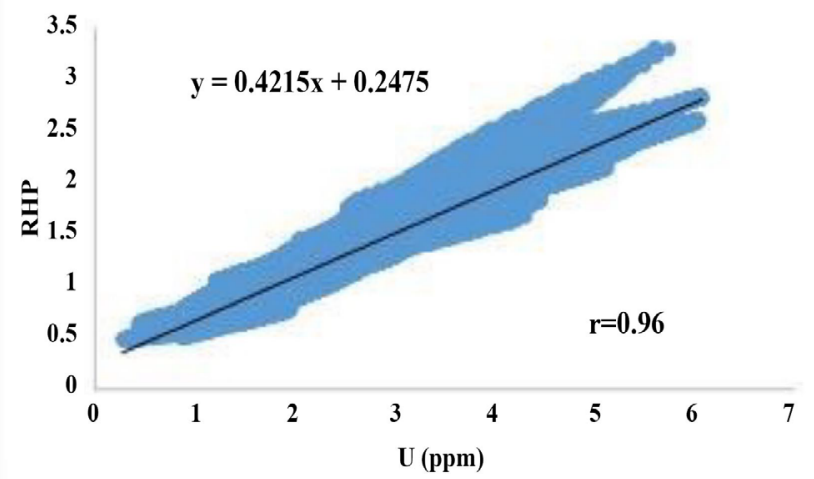

\section{Metavolcanics}

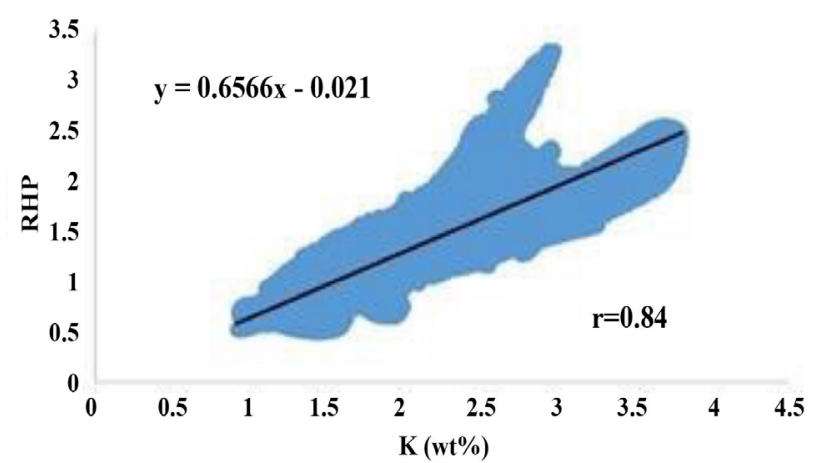

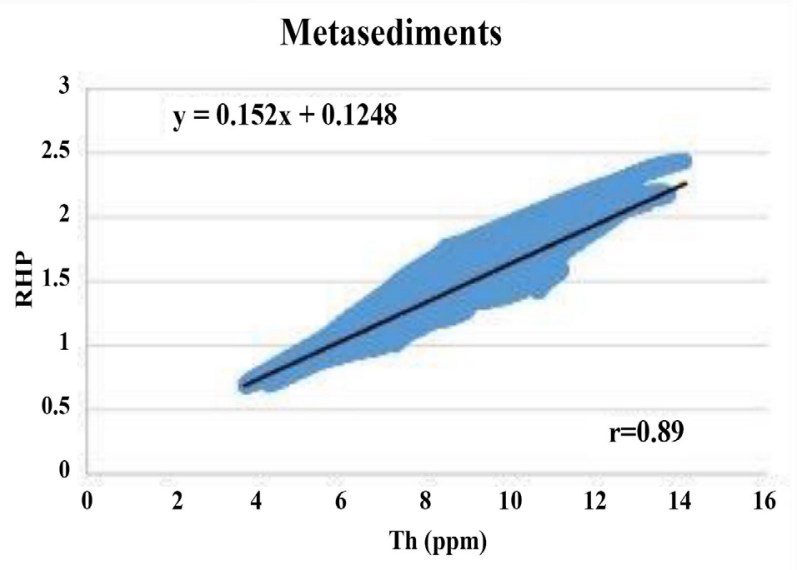

Metasediments

\begin{tabular}{|c|c|c|c|c|c|c|}
\hline & Mean & G. Mean & Min. & Max. & Variance & Std.Dev. \\
\hline Rhp & 1.39 & 1.36 & 0.69 & 2.44 & 0.10 & 0.32 \\
\hline U & 2.68 & 2.58 & 1.25 & 5.09 & 0.55 & 0.74 \\
\hline Th & 8.35 & 8.14 & 3.70 & 14.08 & 3.47 & 1.86 \\
\hline K & 1.88 & 1.83 & 0.94 & 2.98 & 0.16 & 0.41 \\
\hline
\end{tabular}

\section{Metavolcanics}

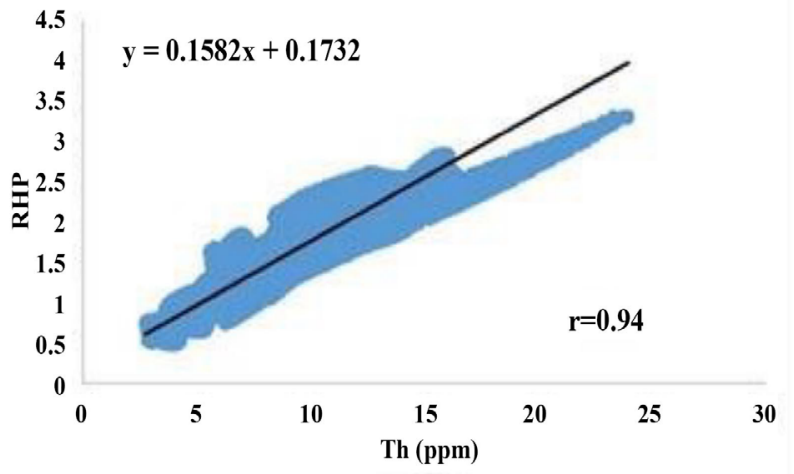

Metavolcanics

\begin{tabular}{|c|c|c|c|c|c|c|}
\hline & Mean & G. Mean & Min. & Max. & Variance & Std.Dev. \\
\hline Rhp & 1.21 & 1.26 & 0.48 & 1.81 & 0.14 & 0.37 \\
\hline U & 2.53 & 2.40 & 0.27 & 6.08 & 0.71 & 0.85 \\
\hline Th & 7.19 & 6.92 & 2.75 & 23.37 & 4.31 & 2.08 \\
\hline K & 2.01 & 1.96 & 0.92 & 3.81 & 0.22 & 0.47 \\
\hline
\end{tabular}




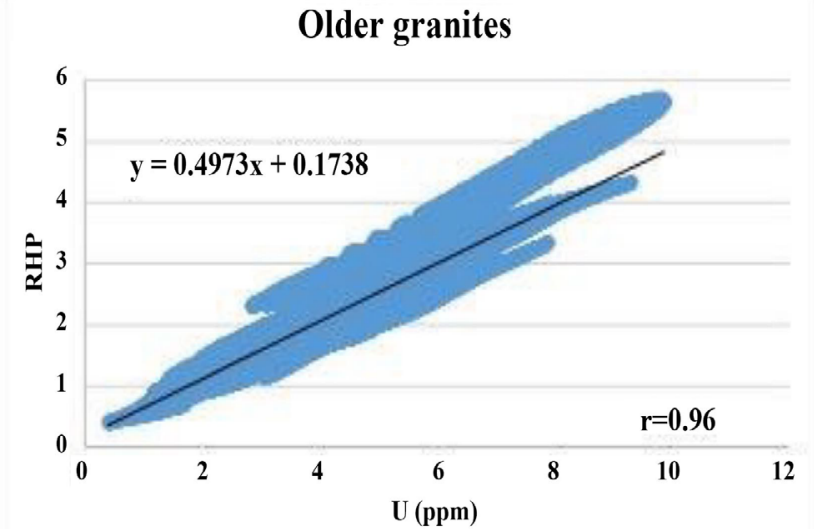

Older granites

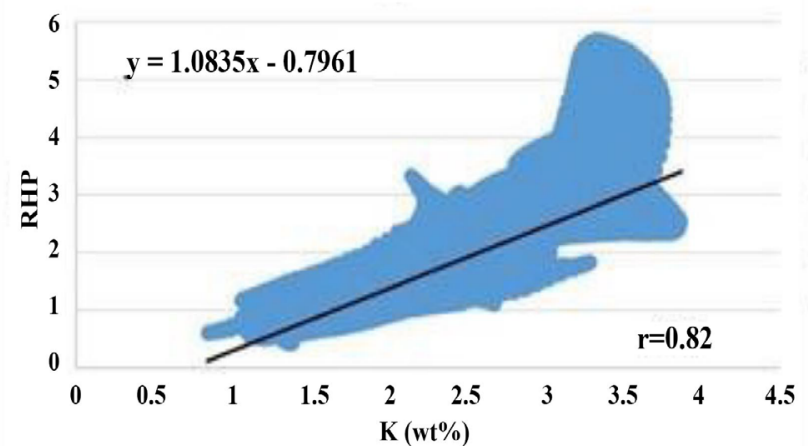

Older granites Calc alkaline

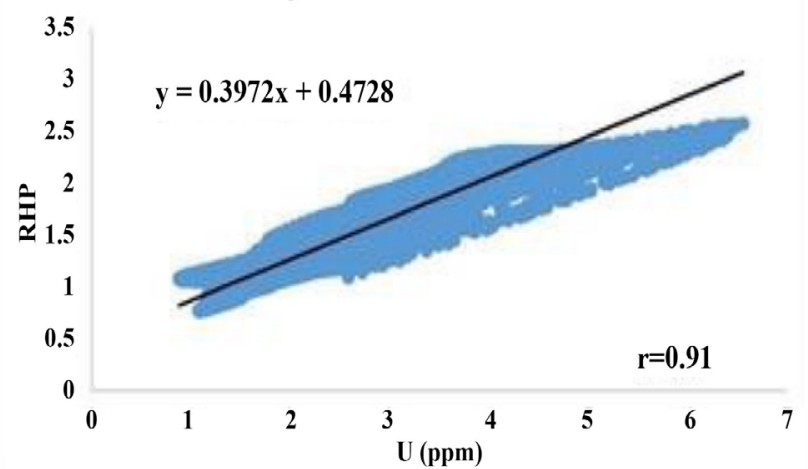

Older granites Calc alkaline

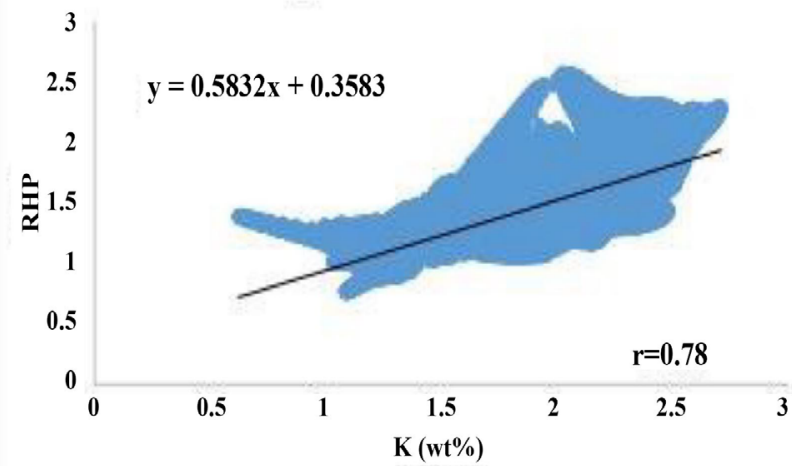

Older granites

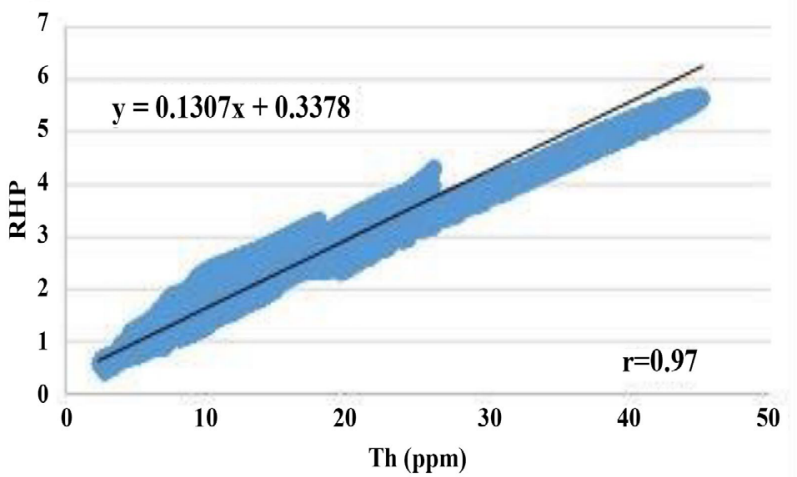

Older granites

\begin{tabular}{|c|c|c|c|c|c|c|}
\hline & Mean & G. mean & Min. & Max. & Variance & Std.Dev. \\
\hline Rhp & 2.26 & 2.15 & 0.73 & 4.54 & 0.51 & 0.71 \\
\hline U & 4.33 & 4.09 & 1.13 & 9.88 & 1.93 & 1.39 \\
\hline Th & 14.65 & 13.75 & 4.51 & 45.27 & 29.48 & 5.43 \\
\hline K & 2.43 & 2.38 & 1.06 & 3.88 & 0.21 & 0.46 \\
\hline
\end{tabular}

Older granites Calc alkaline

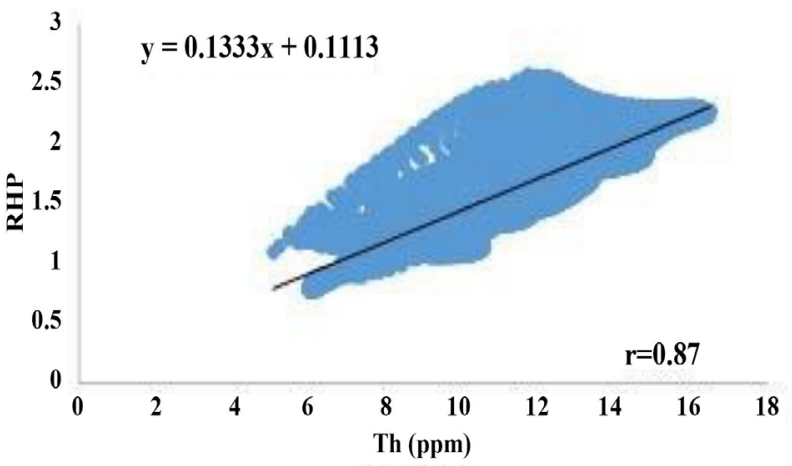

Older granites Calc alkaline

\begin{tabular}{|c|c|c|c|c|c|c|}
\hline & Mean & G. mean & Min. & Max. & Variance & Std.Dev. \\
\hline Rhp & 1.44 & 1.42 & 0.77 & 2.31 & 0.06 & 0.25 \\
\hline U & 2.46 & 2.39 & 0.88 & 4.88 & 0.34 & 0.58 \\
\hline Th & 10.06 & 9.93 & 6.01 & 15.04 & 2.63 & 1.62 \\
\hline K & 1.86 & 1.82 & 0.62 & 2.68 & 0.12 & 0.35 \\
\hline
\end{tabular}



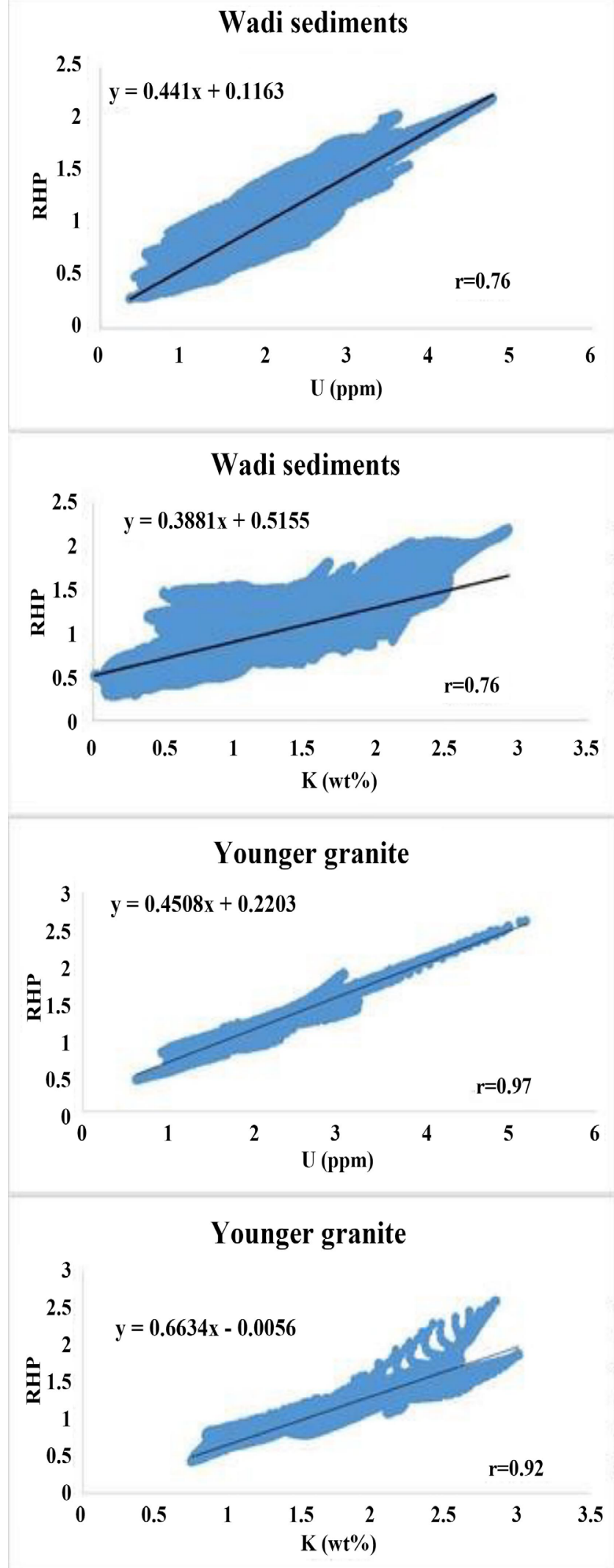

\section{5}

\section{Wadi sediments}

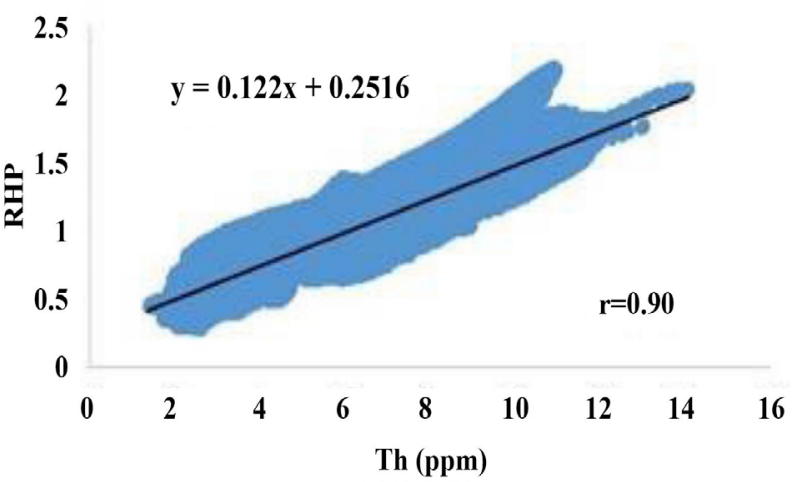

\begin{tabular}{|c|c|c|c|c|c|c|}
\hline & Mean & G. mean & Min. & Max. & Variance & Std.Dev. \\
\hline Rhp & 2.93 & 2.90 & 0.29 & 4.06 & 0.06 & 0.24 \\
\hline U & 1.92 & 1.87 & 0.43 & 3.76 & 0.20 & 0.45 \\
\hline Th & 5.52 & 5.09 & 1.70 & 13.04 & 4.30 & 2.07 \\
\hline K & 0.88 & 0.77 & 0.14 & 2.47 & 0.16 & 0.40 \\
\hline
\end{tabular}

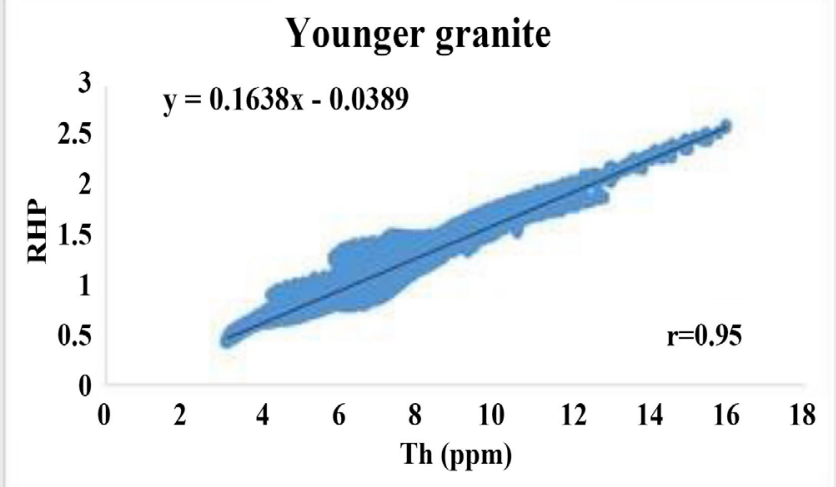

\section{Younger granites}

\begin{tabular}{|c|c|c|c|c|c|c|}
\hline & Mean & G. mean & Min. & Max. & Variance & Std.Dev. \\
\hline Rhp & 3.19 & 3.14 & 0.43 & 5.69 & 0.12 & 0.35 \\
\hline U & 2.72 & 2.27 & 0.11 & 10.42 & 2.83 & 1.68 \\
\hline Th & 8.44 & 6.91 & 1.28 & 27.67 & 33.88 & 5.82 \\
\hline K & 2.07 & 2.00 & 0.75 & 3.51 & 0.29 & 0.54 \\
\hline
\end{tabular}

Figure 7. Binary diagram representing the correlation between RHP and the radiogenic elements with univariate statistics of the studied rock units. 


\section{Conclusion}

The calculated RHP of Jabal Kharazah area are dependent on the radioactive minerals concentrations and the average rock densities. The RHP in the study area range from 0.2 to $5.7 \mu \mathrm{W} / \mathrm{m}^{-3}$ and the average value was calculated as $1.38 \mu \mathrm{W} / \mathrm{m}^{-3}$. The highest values were recorded associated with younger granites, older granites and wadi sediments. More than 95\% from the RHP values are more than the average of RHP in the crust $\left(1 \mu \mathrm{W} / \mathrm{m}^{-3}\right)$, while, about $68 \%$ from readings are more than the average RHP value in the study area $\left(1.38 \mu \mathrm{W} / \mathrm{m}^{-3}\right)$. The results of binary relationships between the RHP and the radioactive elements illustrate that these relations are strongly positive with $\mathrm{eU}, \mathrm{eTh}$ and $\mathrm{K}$ for the studied rock units of Jabal Kharazah area.

\section{Conflicts of Interest}

The author declares no conflicts of interest regarding the publication of this paper.

\section{References}

Aziz, R. N. (2014). Integrated Geophysical and Remote Sensing Studies to Detect Mineralization Zones at Gabal Dara Area, Eastern Desert, Egypt (154 p.). Ash Sharqiyah, Egypt: Zagazig University.

Bücker, C., \& Rybach, L. (1996). A Simple Method to Determine Heat Production from Gamma-Ray Logs. Marine and Petroleum Geology, 13, 373-375. https://doi.org/10.1016/0264-8172(95)00089-5

Clauser, C. (2011). Radiogenic Heat Production of Rocks. In H. Gupta (Ed.), Encyclopedia of Solid Earth Geophysics (2nd ed.). Dordrecht: Springer. https://doi.org/10.1007/978-90-481-8702-7_74

Conoco Coral \& EGPC (1987). Geological Map of Egypt, NG $36 \mathrm{NW}$ Asyut, Scale 1:500,000.

Conoco Coral \& EGPC (1988). Geological Map of Egypt, NH 36 SW Beni Suef, Scale 1:500,000

Fernàndez, M., Marzán, I., Correia, A., \& Ramalho, E. (1998). Heat Flow, Heat Production, and Lithospheric Thermal Regime in the Iberian Peninsula. Tectonophysics, 291, 29-53. https://doi.org/10.1016/S0040-1951(98)00029-8

Hasterok, D., Gard, M., \& Webb, J. (2018). On the Radiogenic Heat Production of Metamorphic and Sedimentary Rocks. Geoscience Frontiers, 9, 1777-1794. https://doi.org/10.1016/j.gsf.2017.10.012

Jaupart, C., Labrosse, S., \& Mareschal, J. C. (2007). Temperatures, Heat and Energy in the Mantle of the Earth. In D. Bercovici (Ed.), Mantle Dynamics, Treatise on Geophysics (Vol. 7, pp. 253-303). New York: Elsevier Scientific Publishing Company. https://doi.org/10.1016/B978-044452748-6/00114-0

Lachenbruch, A. H. (1970). Crustal Temperature and Heat Productivity: Implications for the Linear Heat Flow Relation. Journal of Geophysical Research, 75, 3291-330. https://doi.org/10.1029/JB075i017p03291

Lowrie, W. (1997). Fundamentals of Geophysics. Cambridge: Cambridge University Press.

McDonough, W. F., \& Sun, S. (1995). The Composition of the Earth. Chemical Geology, 120, 223-253. https://doi.org/10.1016/0009-2541(94)00140-4 
Pollack, H. N., \& Chapman, D. S. (1977). On the Regional Variation of Heat Flow, Geotherms and Lithospheric Thickness. Tectonophysics, 38, 279-296.

https://doi.org/10.1016/0040-1951(77)90215-3

Rybach, L. (1986). Amount and Significance of Radioactive Heat Sources in Sediments. In J. Burrus (Ed.), Collection Colloquies Seminars 44, Thermal Modelling in Sedimentary Basins: Paris Editions (pp. 311-322).

Salem, A., Abouelhoda, E., Alaa, A., Atef, I., Sachio, E., \& Keisuke, U. (2005). Mapping Radioactive Heat Production from Airborne Spectral Gamma-Ray Data of Gebel Duwi Area, Egypt. Antalya, Turkey: Proceedings World Geothermal Congress.

Shaaban, M. A. (1973). Geophysical Studies on the Lead Zinc Mining District between Quseir and Mersa Alam, Red Sea Coast, Eastern Desert, Egypt. Cairo, Egypt: Cairo University.

Stacey, F. D., \& Davis, P. M. (2008). Physics of the Earth (4th ed.). Cambridge: University Press. https://doi.org/10.1017/CBO9780511812910

Swanberg, C. A. (1972). Vertical Distribution of Heat Generation in the Idaho Batholiths. Journal of Geophysical Research, 77, 2508-2513.

https://doi.org/10.1029/JB077i014p02508

Thompson, P. H., Judge, A. S., Charbonneau, B. W., Carson, J. M., \& Thomas, M. D. (1996). Thermal Regimes and Diamond Stability in the Archean Slave Province, Northwestern Canadian Shield, District of Mackenzie, Northwest Territories (pp. 135-146). Canada: Geological Survey of Canada. https://doi.org/10.4095/207882 